\title{
UNIVERSITYOF
}

FORWARD

THINKING

WESTMINSTER用

WestminsterResearch

http://www.westminster.ac.uk/westminsterresearch

Justifying and resisting public park commercialisation: The battle for Battersea Park

Smith, A.

This is a copy of the accepted author manuscript of the following article: Smith, A. (2018) Justifying and resisting public park commercialisation: The battle for Battersea Park, European Urban and Regional Studies, DOI: 10.1177/0969776418767731. The final definitive version is available from the publisher Sage at:

https://dx.doi.org/10.1177/0969776418767731

(C) The Author(s) 2018

The WestminsterResearch online digital archive at the University of Westminster aims to make the research output of the University available to a wider audience. Copyright and Moral Rights remain with the authors and/or copyright owners.

Whilst further distribution of specific materials from within this archive is forbidden, you may freely distribute the URL of WestminsterResearch: ((http://westminsterresearch.wmin.ac.uk/).

In case of abuse or copyright appearing without permission e-mail repository@westminster.ac.uk 


\section{Justifying and resisting public park commercialisation: The battle for Battersea Park}

\section{Abstract}

Urban parks have always been contested and contradictory spaces: highly ordered and elitist, yet valued as democratic places and public amenities. In an era of neoliberal austerity there are greater pressures for parks to pay for themselves and the associated commercialisation often exacerbates conflicts between park users and managing authorities. This paper focuses on how their increased use as venues for commercial events affects the publicness of urban parks. This issue is explored via the case of Battersea Park in London which was used as a venue for Formula E motor races in 2015 and 2016. These events disrupted park access during race weekends, but also in the periods when the venue was assembled / disassembled. The events were resisted by a community action group whose campaigning eventually resulted in the decision by Formula E to cease racing in Battersea Park. The paper analyses how Formula E events were justified and opposed using a form of rhetorical analysis inspired by the work of Michael Billig. Interviews were undertaken with key stakeholders involved in the case and their arguments were analysed to reveal different ways of thinking about public parks. The dispute is understood as one underpinned by different interpretations of who and what a park is for, and by contrasting views on the impact of interruptions to everyday routines. The Formula E events reduced public access, but the dispute surrounding the events arguably made Battersea Park more public by generating debate and by provoking local activists to defend their park. 


\section{Justifying and resisting public park commercialisation: The battle for Battersea Park}

\section{Introduction}

In 2016 Battersea Park's Pump House Gallery hosted an exhibition entitled 'The Grounds We Tread' featuring several artists' take on the idea of public space. However, visitors to Battersea Park were about to witness an installation that challenged attitudes to public space in a more visceral manner. A day after the exhibition closed, contractors moved into this South London Park to install a race track for Formula E motor racing - the start of a three week period when access to this historic site was severely restricted. These events were justified as ways to generate funds to help pay for the Park and to promote the use of electric cars, but they were resisted strongly by a group of local residents. The research presented here explores this controversy and uses it to examine the way we think about public parks.

Some of the most important work on public spaces is based on case studies of parks (e.g. Mitchell, 2003) and this paper follows in this tradition by examining one of London's most famous parks. Battersea Park is a large, centrally located park that gained fame for its role in the 1951 Festival of Britain. However, published research on this case is limited to reviews of it historical significance, and this paper aims to provide a much needed account of contemporary challenges. Large parks in city centres are highly regulated spaces used to communicate the values of ruling elites (Harvey, 2013; Low et al., 2009), but they are also democratic spaces where people relax, play and demonstrate (Arora, 2015; Churchill et al., 2017; Gilmore, 2017). This multi-functionality and polysemy inevitably leads to disputes between different users, and between users and the authorities responsible for managing parks (Lowes, 2002; Madden, 2010; Mitchell, 2003). Conflicts are also explained by the 
different ways that parks are valued: whereas citizens appreciate their use value or symbolic value, other interests seek to exploit their exchange value (Harvey, 2009; Lang and Rothenberg, 2017; Mitchell, 2017). Such conflicts are more common in the contemporary era when park authorities are dealing with reduced levels of government funding by generating more commercial income (Smith, 2016; 2017). In this era of neoliberal austerity, when we have seen the rise of the experience economy (Pine and Gilmore, 1999) and the eventful city (Richards and Palmer, 2010), urban parks are increasingly being used as venues for music festivals, sports events and trade exhibitions (Schweinsberg et al., 2017). The dispute analysed in this paper needs to be seen in this context, as an example of the way public space is increasingly contested in eventful cities (Smith, 2016).

Disputes about staging commercial events in city parks involve multiple dimensions, so to provide focus this paper addresses three main research questions: how do these events affect the publicness of parks; how are events justified and resisted; and what attitudes underpin the arguments of proponents and opponents? These questions are addressed by undertaking detailed research into the Formula E races staged in Battersea Park. Following Lowes (2002), this type of dispute is conceived as a discursive struggle and, therefore, rather than focusing on the material effects of staging the events, emphasis is placed on the arguments, discursive frames and rhetorical tactics used by event advocates and opponents. Interviews were undertaken with key stakeholders involved in the case and these were analysed using a form of rhetorical analysis inspired by the work of Michael Billig (1991; 1996). In the following pages, the context of the research is further outlined and relevant research that explores events and urban public spaces is reviewed. A brief account of the methodology is then provided, followed by an extended introduction to the controversy surrounding the Formula $\mathrm{E}$ races in Battersea Park. The arguments used to justify and resist these events are then 
outlined using a structure which reflects three key themes that emerged from the interviews: who the park is for, what it is for and temporal disruption. The paper culminates in a discussion that explores the significance of event disputes and the park 'imaginaries' that underpin them. Ultimately, the paper furthers our understanding of the politics of urban public spaces by revealing what underpins conflicting attitudes in park disputes and by highlighting that opposing positions draw heavily on each other. The work explains how park conflicts make spaces more public by generating debates about who and what parks are for and when they can be used - and by provoking local activists to defend their park.

\section{Public spaces in an era of neoliberal austerity}

The large volume of academic literature on urban public spaces tends to paint a rather depressing picture of their publicness, with the era of neoliberalism associated with greater commercialisation, privatisation and securitisation. However, as both Harvey (2013) and Mitchell (2017: 507) argue, whilst capitalism inherently involves closing down public space, the struggles of social movements and the 'invention of new modes of urban sociability' mean public spaces are simultaneously opened up. Following this logic, rather than debating whether we are witnessing the 'end of public space', it is perhaps more helpful to think about the ends to which public spaces are put (Mitchell, 2017). Financial constraints and political ideologies in an era of austerity mean that public spaces are increasingly seen as strategic investment opportunities for the public sector (Besussi, 2016). This is part of a wider process which Sassen (2017) describes as the financialisation of the city and its repositioning as a commodity. In this context, public parks are regarded as 'assets' or 'under-exploited commodities' that can be 'sold off or leased for commercial use' (Churchill et al., 2017: 12). In the era of government austerity which has followed the 2008 global financial crisis, this 
approach has been more intensively and extensively adopted by UK local authorities facing unprecedented cuts to their funding from national government (Meegan et al., 2014). As Meegan et al. (2014: 180) argue, these cuts have forced local authorities to restructure the ways they deliver public services, something which is 'opening up spaces for the more extensive and intensive commodification of the public sphere'. The available literature on the strategic use of public assets in an era of austerity tends to focus on property initiatives and real estate income. This paper adds to the literature by analysing the ways local authorities are realising the value of public spaces by generating income from commercial events.

\section{Public spaces as event venues}

Many historic public spaces were conceived as settings for events and this design consideration remains important today, albeit with a slightly different emphasis. Crilley (1993: 147) suggests the contemporary public realm is deliberately shaped as theatre 'in which the public basks in the grandeur of a carefully orchestrated corporate spectacle'. In recent years, Crilley's interpretation has become even more relevant as our public spaces are used more regularly for commercial events. This is driven by city marketing objectives and by the need to generate financial returns for the authorities tasked with managing public spaces (Smith, 2016). As Nemeth (2009: 2473) points out 'cities often rent out their central public squares for corporate or commercial events' a trend that now also extends to public streets and parks. The resultant 'eventification' of public space is controversial as it can contribute to processes of privatisation and commercialisation (Smith, 2016). Jakob's (2012) research in Berlin and New York suggests eventification involves the transformation of urban space into staged experiences aimed at wealthy, white consumers. Similarly, Madden's (2010) account of New York's Bryant Park illustrates how events erode the traditional role of 
parks as spaces of representation by repoliticising them as spaces for consumption. Echoing the concerns of many other authors, Keul (2015: 51) feels the city 'has become a place where rights to occupy spaces are increasingly rooted in one's ability to make purchase of them'. Events are significant contributors to this trend, not just because of the price of tickets, but because they aim to attract people willing and able to spend money in city centres (Van Deusen, 2002).

A variety of events are staged in public spaces and whilst exclusive, ticketed events might be regarded as commercial 'incursions' that render spaces less public, other events can help to create activity and sociability - thus making space more public (Smith, 2016).This counter argument challenges the dominant narrative of planned events as agents of appropriation (Citroni and Karrholm, 2017). Events can be used to make a public space 'more pleasant and broaden its user base' (Zukin. 2010) and to change the meaning of established places (Smith, 2014). They can make the public character of public spaces more visible (Citroni and Karrholm , 2017), create temporary 'assemblages' of people and materials (Sendra, 2015), and encourage different users and uses once they have ended (Lehtovuori, 2010). Drawing on Simmel's work, Pløger (2010) uses the term 'eventalisation' to refer to instances where temporary events highlight the potential for heterotopic use of urban space. In such analysis we see convergence between the notion of an event as an organised gathering of people and the idea of an event as a significant rupture of convention. According to Gaffikin, Mceldowney and Sterrett (2010), changing the perception and social use of urban public spaces demands intervention that writes a new script; and events can act in this disruptive fashion, creating revised narratives and alternative modes of social ordering (Pløger, 2010).

\section{Contested park events}


The increased use of public spaces as event venues has been highly contested, and the trend for staging music festivals, sport events and exhibitions in urban parks is particularly controversial. Alongside concerns about commodification and commercialisation, these events disrupt park access for a significant period of time during events and whilst temporary structures are assembled and disassembled. Damage to environments can mean that events lasting a few days can result in disruption lasting several weeks. In London there is growing demand to use the city's renowned parks as venues and, as a result, there are ongoing disputes between park users and event interests. It is no coincidence that these have emerged in the wake of the 2012 Olympic and Paralympic Games, when many London's parks were used for events on an 'exceptional' basis - setting a precedent for future use (Smith, 2014). In Hyde Park, there are regular complaints about the events staged on the Parade Ground, a large site which is 'closed to the public for the safe-build and break-down of events for the equivalent of 12 weeks per year' (Hansard, 2016). Meanwhile, The Friends of Finsbury Park continue to campaign against Wireless, a musical festival that is staged each summer, arguing that the event illegally excludes members of the public from a significant proportion of Finsbury Park. Users of Gunnersbury Park (West London) and Brockwell Park (South London) are also campaigning against the growing number of major events which they feel are usurping the traditional functions of these public spaces.

The protests described above encompass a range of different concerns and interests, but they are part of the growing resistance to the neoliberal enclosure of public space. As Mayer (2013) argues, austerity cuts have now begun to hit more affluent citizens - as well as the disadvantaged - and this has led to a growing number of middle class urbanites who are keen to defend their accustomed way of life. The enclosure of public space to form corporate and 
elite enclaves has prompted a new wave of resistance from citizens who have coalesced under the idea of 'the right to the city' (Harvey, 2013; Mayer, 2013; Mitchell, 2017) and the rise of commercial events in London's parks provides a good example of this trend. Exploring middle class opposition to park events might seem less significant than analysing the fate of evicted tenants or oppressed citizens, but these campaigners should not be dismissed - their causes, tactics and impacts deserve attention. As Mayer (2013: 13) argues: 'if the privileged urban movements would add their leverage to the struggle against the exclusivity of neoliberal urbanism, the weakness of traditional urban activism might actually be overcome'.

The case analyse here involved motor races which are perhaps the most disruptive and controversial events staged in public parks. Ever since the Australian Formula 1 Grand Prix was moved to Melbourne's Albert Park in 1994, the Save Albert Park Group has campaigned against this event which causes four months of annual disruption. Indeed, whilst the Grand Prix is justified on grounds of economic impact, Fairley et al. (2011) estimate the race results in $\$ 1.7$ million of community costs - including the loss of amenity. According to Lowes (2004: 73), the Grand Prix represents a privatisation of Albert Park and is 'counter to the integrity, purpose and core philosophy of this profoundly public space'. Using Iveson's (2007) conceptualisation, the event diminishes topographical public space, but also procedural public space - that which is used for collective action and debate. A special Grand Prix Act was introduced to provide a legal justification for the Melbourne Grand Prix; and this legislation is also designed to hinder protests and demonstrations (Lowes, 2004). Other Australian cities also stage motor races in their parks: for example, V8 races are staged in Adelaide Parklands (Tranter and Lowes, 2009) and in Sydney Olympic Park (Davidson, 2013). These events are driven by a mixture of place marketing and motorsport marketing 
objectives: they promote host cities to external audiences and the park locations draw in audiences that wouldn't normally attend motor racing (Tranter and Lowes, 2009).

Lowes' (2002) analysis of plans to relocate an IndyCar race from False Creek to Hasting Park in Vancouver is particularly relevant to this paper. The case has obvious parallels with the Battersea Park case analysed here which also involved controversial motor racing events that were successfully resisted by local people. The Vancouver dispute was 'a discursive struggle' between race advocates and local community groups (Lowes, 2002: 118). Proposals were successfully resisted by the Hastings Community Association who managed to counter the boosterism of race organisers with their own powerful rhetoric. Local campaigners were cast by their opponents as selfish 'carpers' and 'naysers', but they managed to construct an alternative vision of Hastings Park that resonated with people. Success was achieved by presenting a different type of 'common-sense' to the one promoted by race organisers. Lowes' (2002) research highlights the importance of analysing the rhetoric used by both event advocates and local campaign groups - something that guided the design and emphasis of the research presented in the remainder of this paper.

\section{Methodology}

The controversy surrounding the staging of Formula E motor racing in Battersea Park is the focus for the present study. This case was selected because it provided an insightful example of the way London's parks are increasingly deployed as commercial event venues. Given it involved creating a motor racing venue in a Grade II listed park, the case represents a relatively extreme example, but, as Flyjberg (2006) suggests, extreme cases can be rich vehicles for understanding a problem or issue. The case study was researched using a 
combination of qualitative methods. Key individuals were identified and interviewed using a flexible schedule that was customised to each participant. Interviewees included pivotal figures who represented the main stakeholders in the project: the event organisers (Formula E); the local authority (Wandsworth Borough Council); the organisation responsible for parks in Wandsworth (Enable Leisure and Culture) and the group that formed to resist the events (Battersea Park Action Group [BPAG]). Officials representing relevant interest groups were also interviewed: including the Open Spaces Society, Parks Alliance, London Green Spaces Friends Groups Network, Parks for London and the Heritage Lottery Fund (HLF). Interviews were also conducted with event interests including officials from London and Partners (the Mayor's official promotional agency), CSM (one of the world's leading sport and entertainment marketing companies) and the National Outdoor Events Association (NOEA). All interviews were undertaken in the period just before and just after the staging of the 2016 edition of the races. These interviews, which lasted between 45 and 95 minutes, were transcribed verbatim and then analysed using NVIVO software.

In the data analysis particular focus was placed on uncovering the rhetoric used by event advocates and opponents to justify / contest the use of Battersea Park as a venue for Formula E races. This approach was informed by rhetorical analysis (Billig, 1991; 1996); a strand of discourse analysis developed by social psychologists that is often overlooked by urban geographers (e.g. Lees, 2004). Rhetorical analysis is 'particularly useful' for urban policy researchers 'interested in analysing, in detail, data gathered from interviews' (Jacobs, 2006: 42), hence its use here. Billig (1991) regards thinking and the holding of opinions as something that is both ideological and rhetorical. He argues that there is a value is analysing argumentation and uncovering the way that arguments shape the way we think about certain issues. Rather than trying to understand the inner psychology of people, attitudes can be 
analysed by analysing outer, rhetorical meanings (Billig, 1996). Di Masso et al. (2011) use this type of analysis to examine struggles over public space in Barcelona and a similar approach was adopted in this study. The aim was not merely aim to summarise the arguments made, but to understand if and how these arguments incorporate counter-arguments. As Billig (1996) notes, affirmation and negation are intertwined in argumentation and it is important to explore how views are expressly designed to undermine plausible alternatives (Di Masso et al., 2011). Billig (1991) stresses the importance of studying thinking and opinion in their wider social context, so there is also an attempt to understand the links between argumentation and broader ideological positions.

Once examples of argumentation were identified in the transcripts, this data was then analysed using a form of thematic analysis recommended by Braun and Clarke (2006). This involved familiarisation with the data; generating initial codes; searching for themes; reviewing themes; defining and naming themes; and then writing up the analysis. The themes created from the initial codes are reflected in the titles of the three subsections in the research findings detailed below (who is the park for / what is the park for / temporal disruption).

Interviews were complemented and contextualised by the collection and analysis of various secondary documents (media reports, planning applications and policy statements) and by a series of observation exercises undertaken in Battersea Park during the summer of 2016. The researcher completed over 30 hours of observations on 10 different occasions between $18^{\text {th }}$ June and $3^{\text {rd }}$ August including five hours on one day of Formula E racing ( $2^{\text {nd }}$ July). These observations allowed the researcher to better understand the issues discussed by interviewees and to compare their rhetoric with in situ experiences. 


\section{Formula E in Battersea Park}

Battersea Park is a large municipal park located on the south bank of the River Thames in central London. It was officially opened in 1858 as part of the pioneering first wave of public parks that were designed to help address rapid urbanisation and social problems in UK cities. The Park is now managed on behalf of Wandsworth Borough Council by Enable Leisure and Culture; a not for profit company conceived to supplement local authority funding.

Wandsworth is regarded as one of the Conservative Party's flagship local authorities and it has always been keen to follow the neoliberal prescription that public parks should be financially self-sustaining (Loughran, 2014). This philosophy has caused various conflicts, including a recent dispute over a Go Ape facility that requires users to pay £18-33 to climb apparatus installed in the treetops. Indeed, the Formula E controversy explored here needs to be understood within the context of Battersea Park's history as a highly contested site which has been threatened by commercial incursions for several decades.

Formula $\mathrm{E}$ is a new motor racing franchise involving electric cars that was established in 2014 by a Spanish entrepreneur, with the backing of the Federation Internationale d'Automobile (FIA). The series aims to advance new sustainable technologies and to promote the use of electric vehicles (Interview with Formula E). To achieve these objectives and to provide differentiation from other motor racing franchises - the races take place on urban street circuits. The origins of staging Formula E events in Battersea Park date back to 2013 when Wandsworth Council were first approached about hosting races. Initially the proposal was turned down, but Formula E came back with a better financial offer and one that involved a less damaging way of installing the circuit (Interview with Wandsworth Council). Formula $\mathrm{E}$ officials were attracted by the layout of Battersea Park which reminded 
them of a race track; and they also liked the way that all the support services could be contained within the Park's boundaries (Interview with Formula E).

A five year contract was agreed that required Formula E to pay Wandsworth Council $£ 1$ million per annum for the rights to stage two days of racing each year. In the context of cuts to local authority budgets this was a significant sum of money, and the Council promised that $20 \%$ of the funds ( $£ 200,000$ per annum) would be spent on improvements to Battersea Park. The races were scheduled as the climax to the inaugural 2014/ 15 Formula E season but, when details were released, opposition emerged. Local people reacted strongly to the proposal to convert Battersea Park into a race track, but they were also angry about the lack of consultation and communication. Council approval and planning permissions were gained despite objections from local people who expressed concern about the impact of event structures on park environments, the restrictions on park access and the disruptive work required to install the track (Wandsworth Borough Council, 2014).

Formula E events were justified by Wandsworth Council in several ways. The Councillor who championed them felt they were warranted because of the financial and wider economic benefits, but also because the events would help to change people's attitudes towards electric cars. He also felt the events were something that would make Battersea Park 'as accessible and as visible as possible so that a maximum number of people can enjoy it' (Interview with Wandsworth Council). The argument that the events were inappropriately exclusive was directly countered by representing the Formula E races as public events, rather than exclusive, private occasions: 'It's very much a family event - very young kids came ... schools were very much involved' (Interview with Wandsworth Council). The composition of the crowd also helped to explain why Formula E wanted to stage the races in an urban park 
despite the added complications this caused. Formula E wanted to 'appeal to a completely different demographic' who 'would never buy a ticket to go to Silverstone or a Grand Prix' (Interview with Formula E). The events were therefore justified as mutually beneficial: Formula E would help to bring different people to Battersea Park; and Battersea Park would bring different people to Formula E.

Once preparations for the 2015 edition began, opposition to the events began to grow. The race circuit was surrounded by metal fences mounted on concrete blocks and related deliveries and construction work created major disruption. Formula E acknowledged the effects this had on park users: 'The impact is visceral right there, right then, when they're walking their dog and a forklift is just over there behind a fence putting a concrete block in' (Interview with Formula E). Preparations meant park access was disrupted not just during the weekend of races, but for two weeks beforehand, and for several days afterwards whilst the structures were removed. An attempt was made to keep some of the park open at all times, but for the race weekend - and for two subsequent days - the vast majority of Battersea Park was closed. When people visit public parks and find the gates locked this has a symbolic as well as a practical impact on users (Interview with HLF). Campaigners were concerned about permanent physical effects too: various interventions were needed to make the carriageways more suited to racing cars; and the BPAG suspected that newly tarmacked areas would be deliberately retained as they would facilitate future events and other commercial activities (Interview with BPAG).

Despite opposition to the 2015 event, Wandsworth Council decided not to activate the break clause in their contract with Formula E and applied to host the races again in 2016. This time, opposition was more organised and targeted at Formula E sponsors. The BPAG used social 
media effectively and they also promised direct action if the 2016 races went ahead. The BPAG organised the crowd funding of a Judicial Review fronted by a blind author who regularly used the Park, but just before this was due to be heard in the High Court, Formula E reached an out of court agreement with the BPAG. They promised that this would be the last time Formula E races would be staged in Battersea Park as long as the BPAG ceased all campaigning and allowed the 2016 races to proceed without disruption.

Who is the park for?

In trying to justify or oppose the Formula E events, stakeholders often made reference to who Battersea Park was for and how the part-closure of the Park affected these users. A recurring theme was the way Battersea Park provided a garden for local people who did not have access to their own private gardens. For example, the BPAG representative argued that the events denied access to 'people who really need it': 'I would say of the four wards around the Park probably $90 \%$ of the 50,000 people do not even have a backyard or a balcony. It is their garden.' Garden references were also used by Formula E opponents to argue that the events were conceived by privileged officials fortunate enough to live in houses with private gardens - making them oblivious to the needs of people without such access.

Formula E advocates argued that the people complaining about the events were residents of nearby mansion blocks not disadvantaged people without access to gardens: 'They would say, we don't have a garden. You presumably knew that when you bought your fancy apartment block on the third or fourth floor, it didn't have a garden' (Interview with Wandsworth Council). This type of rhetoric helped to reinforce the wider argument that opponents were selfish and over-privileged. Event advocates equated local people's 
attachment to Battersea Park with a conservative possessiveness that ignored the regional and national status of the Park: 'They feel an ownership of it. They treat it as their back garden and they don't want things to be in there that they see as being different' (Interview with Formula E). This sense of ownership was dismissed as selfishness: 'There were people who were saying, more bluntly than I would ever get away with, don't be selfish, this is great. Sure, there's going to be a bit of disruption to the park. It's not your back garden' (Interview with Wandsworth Council). The use of the term 'back garden' in these quotes is significant because it emphasised this was a position adopted by selfish NIMBYs.

The dispute also involved other arguments linked to theme of who Battersea Park was for. Advocates of the events justified them by arguing that they were good ways of diversifying the profile of park users. For example, the Parks for London representative argued:

'There are some people who will never go in a park and the only thing that brings them in is the event and then when they're in, they actually have a look around and think, oh my gosh, I didn't know this was here'.

In a similar manner, Formula $\mathrm{E}$ argued that their event appealed to younger, less privileged people who might not otherwise use Battersea Park:

'there are some very big housing estates around there and the people that were complaining were the people that live by and large in some very nice, very expensive houses right on the edge of the park. What we were trying to do was get the message to the people that live just beyond there that this event is for them. It's urban...' 
Unsurprisingly, this view was rejected by opponents of the Formula E races, who felt that staging expensive and exclusive events further distanced disadvantaged groups from Battersea Park. As the Friends Network representative put it: 'The point about a big commercial event is that it's a consumerist event. ...making it exclusive'. Similarly, the representative of the Parks Alliance argued that events such as Formula E 'do bring different users into parks but they will bring people who've got money in their pocket.' These views reflect wider concerns that parks are increasingly provided for consumers, rather than citizens (Madden, 2010).

What is the park for?

Disagreements between advocates and opponents of the Formula E events were also underpinned by different ideas about what parks are for. Some interviewees felt Formula E events were something that could add excitement and entertainment to a space regarded as old fashioned or outdated. For example, the Parks for London representative felt that Victorian parks 'need to grow up and reflect the cultural change and societal change that's taken place since they were first created. And so I think we should be open to innovation'. This was also the stance taken by the representative from Enable Leisure \& Culture who felt that people want parks to stay the same and be havens of tranquillity when they should be 'dynamic' and 'active places'. But this position was directly rejected by opponents of the events who extolled a very different interpretation of the value of parks. For example, the Open Spaces Society - who campaigned against the Formula E events - contested the idea that parks need to be made more up to date: 
'You don't want it to be more $21^{\text {st }}$ century, do you? The whole point, and all research shows this, is that having quiet places where you can contemplate and walk your dog is refreshing and therapeutic. If I' $m$ in a park ...we want to sit and be quiet, you know, let the kids play on the swings maybe. That's what it's about. There's nothing $21^{\text {st }}$ century or $19^{\text {th }}$ century about that, it's a basic human need'.

Staging motor racing represents a rather extreme way of diversifying the functions of traditional parks. This was acknowledged by opponents of the events, who felt that motor racing was simply inappropriate for park settings. The Friends Network representative made his position clear:

'I mean how is racing cars acceptable in a public park? In fact we spend a lot of time here trying to tell people not to come in on their motorbikes and cars and race around the park. Because it's an entirely inappropriate activity for a park. It's totally ridiculous. If you're going to race cars, why don't you go to the road? Close down the main streets or whatever and do it there'.

This commonly held view was directly countered by advocates of the events who felt that motor racing in parks was justified because there were precedents, and because of the excitement they bring:

'I remember as a child going to Crystal Palace Park when they had proper Formula 1 racing cars racing around there and I remember, God, it was so loud, but it was so exciting. So these things have taken place, there is a precedent for them and I'm not saying every park should become a racetrack and built over and all that, but I think 
technology has moved on so much. There are ways and means of doing things which are less damaging to the environment but could bring a lot of joy, pleasure, interest.' (Interview with Parks for London).

\section{Temporal disruption}

A third theme that recurred in the different arguments used to justify and oppose the Formula E events was the notion of time. Advocates of the races acknowledged some of their negative consequences (in particular restricted park access), but felt these were acceptable because of their limited duration. In contrast, those campaigning against the events cited the temporal extent of the disruption as one of their main objections. It was notable how the perceived temporal footprint of the events varied according to different stakeholders. Formula $\mathrm{E}$ fans highlighted that the events only took up one weekend per year, and that there were plenty of alternative green spaces that local people could use instead. On the Formula E radio show (24 ${ }^{\text {th }}$ May 2016), one of the presenters expressed his frustration at the actions of campaigners:

'[its]astonishing that an event that would bring that many people and a fair amount of money to maintain the park - and huge publicity - has been pissed into the wind because a bunch of people couldn't walk their poodles on one Saturday of the year'.

However, opponents pointed out the extensive preparations and de-rig that put 'huge areas of the Park out of bounds for a large amount of time' (Interview with Friends Network). They argued that events such as Formula E are particularly disruptive because they take place at a time when parks would be most heavily used: 'it's usually primetime, during the summer, so it's not two weeks out of 52. It's two weeks out of 12 . Because the average person uses their 
park in the summer' (Interview with Friends Network). However, there was little sympathy for this position amongst event stakeholders who argued that people should anticipate that every summer their parks will be used for major events:

'you know, reasonably frequently, I can enjoy that quiet open space. But equally, reasonably infrequently. I'm going to expect that there is a programme of events that are going on at the time when we are at our busiest or when the weather is at its best' (Interview with London and Partners).

This attitude was shared by other event interests who suggested that opponents of park events were living in the past: 'it's not accepting the reality of the modern world' (Interview with CSM Sport and Entertainment). Opponents were dismissed as old fashioned conservatives who wanted to preserve an outdated conception of public parks - another temporal theme within the argumentation surrounding the Formula E events.

Arguments against the Formula E events also included more subtle temporal dimensions that went beyond simple criticisms of the length, frequency and timing of disruptions. A BPAG representative pointed to the way in which the events interrupted people's regular habits and everyday use of parks. She pointed to the effects this can have on vulnerable people and their carers:

'I had several people almost in tears because they couldn't take their sick relatives into the park in their wheelchairs, and so on and so forth. I mean it's just... it's not just for healthy people like me that go and walk around. I've had several people 
[contact me] who work in the mental health sphere and they say it is essential not just for physical health, fresh air and calm and peace'.

Emotive rhetoric regarding the everyday habits of vulnerable people was matched by event advocates who cited their own examples of residents whose routines were disrupted in a more positive way. The Wandsworth Councillor cited an elderly disabled man who had 'come out for the first time in months for the events'. Similarly, the Parks for London representative referred to a retired gentleman, arguing the events 'got him out of his flat, he got talking to people that he would never have got talking to before'. In these instances, the traditional role of public parks as sociable meeting places is used as part of the warrant for staging Formula E events.

A slightly different take on the temporal effects of the events was the view that any incursion - temporary or permanent - that restricted public access was inappropriate: 'The point is they're public open spaces so having activities temporary or permanent that are about excluding the public or forcing people to pay is actually undermining the fundamental value of green spaces' (Interview with Friends Network). This opposition is based on ideological grounds rather than practical concerns about physical impacts or disruption. In this case, and in others, opposition to the Formula E events was linked to a wider critique of the involvement of commercial interests in public parks.

\section{Discussion}

The dispute over staging Formula E events in Battersea Park highlights the ways that urban parks are being exploited as commercial event venues to help plug holes in local authority 
funding. The main motivations for staging the Formula E races in Battersea Park - income for the local authority and publicity for the park - suggest this is a further example of the ongoing neoliberalisation of urban public spaces. Local authorities now see parks as assets from which they can earn income and, due to their temporary and semi-public nature, commercial events are seen as a palatable way of realising the financial value of parks. The current funding crisis facing local authorities in the UK explains this new emphasis on income generation. Financial crises are known to be 'path shaping moments' (Jessop and Oosterlynk, 2008) and 'laboratories' for new models of urban governance (Oosterlynk and Gonzalez, 2013). This highlights the danger that the current crisis will sanction a reimaging of city parks - pushing them towards a model where the most lucrative uses and users are privileged, and where publicness is sacrificed for publicity.

Whilst it is hard to ignore the rather depressing implications of the rise of commercial events in city parks, Citroni and Karrholm (2017) highlight the possibility of a more positive outcome. In a paper which deviates from the dominant narrative of events as 'appropriation', these authors suggest that events affect public parks by visibilising the nature of their territorial complexity and argue that events can help to reaffirm the publicness of urban parks, a trait which they believe is 'confirmed through its violation'. The Battersea Park Formula E races staged in 2015 and 2016 were definitely a violation, but the disruptive closures reaffirmed the symbolic and functional importance of this space and generated important debate in the public sphere about what and who public parks are for. Park events are part of perpetual de and re-territorialisation processes where the identity of park space is constantly negotiated and renegotiated (Citroni and Karrholm , 2017). Therefore, rather than trying to work out whether they are justified or not, it is perhaps more helpful to consider 
commercial events as part of the struggle for parks that ultimately produces public space (Mitchell, 2017).

The research presented here also illustrates the ways that neoliberal strategies are resisted by local and national interest groups. As Leitner et al. (2007) argue, it is important to analyse neoliberal urbanism and its contestations together, not least because positions and policies are reshaped by the interactions between them. Neoliberal strategies and resistance to those strategies evolve by drawing strategically from each other (Leitner et al., 2007) and this was evident in the present study where advocates of Formula E races borrowed their opponent's arguments about exclusivity and marginalisation to forward their own case. To counter accusations that the races unfairly excluded park users who couldn't afford to attend, they argued that opponents were affluent residents seeking to deny less privileged people access to a public event. Similarly, rather than denying needy beneficiaries their 'right to the city' as their opponents argued, advocates of the Formula E races suggested these events provided opportunities for socialising that could help to integrate marginalised people. Previous research has shown how community action groups can succeed by appropriating the discourses of neoliberalism (Lowes, 2002). This study highlights that this also works the other way round - neoliberal boosters help to bolster their arguments by adopting discourses of their opponents.

By analysing the arguments made by advocates and opponents, we can better understand how the Formula E events were initially sanctioned and then successfully resisted. Conflicts over high profile events are 'discursive struggles' which require detailed analysis of the rhetoric used by key stakeholders (Lowes, 2002). The Battersea Park case revealed various rhetorical tactics that echo those used in other urban disputes. Minton (2017) notes how London's local 
authorities push through radical development policies by using rhetoric that depicts their opponents as red wine swilling, NIMBY homeowners. This 'class war narrative' (Minton, 2017: 74) was also evident in the case analysed here as campaigners were dubbed selfish, conservative and overprivileged NIMBYs. As Burningham et al. (2015) identify, how developers 'construct' their opponents is important because it informs the way they engage with them and influences wider public attitudes. In this case, officials regarded their opponents as a small group of privileged troublemakers and repeated references to 'back gardens' were made to cast them as NIMBYs. This rhetoric was picked up by the media who dubbed the academic who led the Battersea Park Action Group 'Professor NIMBY' (Webster, 2015) - a moniker that race organisers were keen to highlight (Interview with Formula E). Accusations of NIMBYism were part of a wider attempt by Formula E advocates to represent opponents as people motivated by personal inconvenience, rather than as citizens acting in the public interest. This illustrates a wider trend noted here where Formula E advocates tried to de-emphasise the political / ideological significance of Battersea Park's conversion into a motor racing venue, instead preferring to represent the decision to stage the races as a pragmatic one with practical consequences.

By focusing on how different stakeholders argued their cases, the study not only reveals more about event disputes, it helps us to understand contemporary attitudes towards parks. In the preceding analysis arguments regarding the Formula E races were organised into key themes: who parks are for, what they are for, and different interpretations towards temporal disruption. These themes reflect current debates about the prospects for public parks - defined by Churchill et al. (2017: 16) as 'what the park constitutes, appropriate uses of the park, and who parks are for'. The positions taken by the stakeholders interviewed in this study seemed to be based on contrasting park 'imaginaries'. Imaginaries involve a combination of ideals, 
norms, discourses and ethics that help to reduce the complexity of the word into a meaningful and manageable form (Jessop and Oosterlynck, 2008). Imaginaries exist beyond individual's images and imagination (Salazar, 2012) - they are widely shared systems of presumption (Vogler, 2002). In the contemporary era, parks assume very diverse forms, but the participants in this study communicated a very clear idea of what a park means to them. For opponents, the Formula E races were inappropriate for a park setting as these events did not fit with their park imaginary. In an idealistic and nostalgic manner, they regard parks as quiet places for contemplation; and as therapeutic sites to be used for mundane, everyday functions by local people (e.g. jogging, dog walking). This type of imaginary - grounded in Olmsted's notion of parks as refuges from the city - is also evident in the accounts of park traditionalists such as Lasdun (1992: 193) who feels parks 'do not need to supply organised entertainment when situated in a city where it is freely available'. Arguments used to justify the Formula E races were underpinned by a very different imaginary, where parks were regarded as dynamic sites of entertainment and sociability, integrated with - not set apart from - the rest of the city. In this imaginary the park is a 'destination' to visit, a day out which can be enjoyed by a range of people from a range of locations - not just established users who live locally. This is a more modern, flexible interpretation of what and who a park is for - and one which sits more easily with the idea that the exchange value of parks should be realised to secure their future. The modern park imaginary is a less idealistic, and more pragmatic, interpretation of what a park is; and one that consciously disrupts the traditional idea of the park as a refuge from the modern city.

The attitudes revealed here don't merely highlight the conflicting imaginaries held by different stakeholders, they emphasise the ways these imaginaries are actively deployed by vested interests as rhetorical frames through which to persuade others. In reality - through 
effective spatial and temporal management - large parks like Battersea Park can be both tranquil green places and sociable places for entertainment. However, the case analysed here shows how over-simplified park imaginaries are deployed to support arguments for and against park events. Park imaginaries are thus vital mechanisms through which neoliberal parks policies are justified and resisted.

The rhetoric involved in this case study also highlights some important ideas about the temporal accessibility of public space. In parks that have traditional gates and railings (like Battersea Park) access is always limited to official opening times, but the emergence of ticketed events as a regular feature / function of parks further limits access to particular periods. In rhetoric not dissimilar to that revealed by Lowes's (2002) Vancouver study where residents were pressured to accept park events as part of their 'civic duty' - event interests felt that summer disruptions were something park users should expect if they wanted to live in a 'successful', 'world-leading city' (Interview with London and Partners). Again, the restricted access to public space caused by events was represented by event advocates as a practical issue rather than an ideological one. This wasn't necessarily an attempt to depoliticise parks and dilute their traditional role as spaces of representation. Indeed, in a good example of argumentation, one interviewee claimed the commercial and political functions of parks were not mutually exclusive:

'Our parks are the last remaining vestige of a democratic society. They are truly democratic spaces. Now, one could argue, oh, you're arguing against yourself now because these events are making them undemocratic. Well, they're not. They're not, because they are managed, they are for a [limited] period, they're not to replace, they're to supplement' (Interview with Parks for London). 


\section{Conclusions}

The research presented here highlights growing pressures on parks to stage commercial events and the ways these affect the publicness of park spaces. This is part of a wider debate about the commercialisation and privatisation of public space driven by reduced government budgets. The case highlights the inevitability of conflict when policies are pursued that prioritise the exchange value of parks over their use value. Analysing these conflicts helps us to understand the discursive tactics used by different interests to justify and resist commercialisation / privatisation. The paper contributes to our understanding by revealing how key stakeholders think about parks and how these positions influence their attitudes towards entrepreneurial strategies that challenge established notions of what and who parks are for. Qualitative analysis of interview data uncovered the significance of dominant park imaginaries: these not only underpin attitudes towards parks, they are strategically deployed to convince others to support or resist controversial park initiatives. These findings should interest urban scholars interested in the politics of public spaces, but also various park interests who want to know how they can influence, manage and 'win' park disputes.

Commercial events staged in parks are highly contested by some users and the analysis here demonstrates this resistance is not merely based on NIMBYism and fears about direct event impacts (noise, disruption etc.), but on symbolic and ideological concerns too. Urban resistance is usually associated with acute causes such as homelessness and evictions, but in trying to protect their park from Formula E events, members of the BPAG were also campaigning for their 'right to the city' (Mitchell, 2003). However, just as it is unfair to dismiss opposition to park events as NIMBYism, we cannot claim that those supporting park 
events are only interested in commercial revenue and place marketing. This study also revealed some more progressive justifications: challenging traditional conceptions of parks, widening participation, enhancing their relevance and socialising them. These arguments reflect an alternative conception of event outcomes - as 'eventalisation' - that deviates from the dominant narrative of events as vehicles for appropriation (Citroni and Karrholm, 2017).

Disputes such as the battle over Formula E racing in Battersea Park are an inevitable and defining feature of contemporary public spaces. Struggles over events generate debate in the public sphere about what and who parks are for - 'visibilising the nature of the territorial complexity' (Citroni and Karrholm, 2017). It is easy to argue that large-scale, ticketed events inherently compromise the publicness of parks, but following Citroni and Karrhom's (2017: 12) argument, their publicness can be reaffirmed through such violations. Closing large parts of parks for ticketed events reminds us that these are enclosed territories controlled by the state - rather than common property - and, as Harvey (2013: 73) notes, it takes political action on the part of citizens to turn them into public spaces. In this sense, the dispute surrounding the Formula E events - in particular the ongoing efforts of the Battersea Park Action Group has made Battersea Park more public.

The case analysed here is a particularly insightful for analysing the rhetoric involved in event disputes given the fact that Formula E racing in Battersea Park events was sanctioned, realised, and then withdrawn. Various rhetorical tactics have been revealed that help us better understand these types of disputes and their outcomes. Many of the arguments adopted by advocates were examples of 'defensive rhetoric' (Potter, 1996) - negations of the key arguments put forward by the campaigners. For example, the charge that the events were inappropriately exclusive was countered by the notion that they encouraged different types of 
park users. The argument that motor racing was inappropriate in a park setting was flipped to argue that parks needed to be shaken out of their Victorian torpor. These conclusions chime with those of Lowes (2002) who found that groups contesting park events tend to turn discourses back on each other to win over public opinion. This reaffirms the value of rhetorical analysis which reveals how arguments incorporate counter-arguments; and how this argumentation reveals and shapes the way we think about places (Di Masso et al., 2011).

Traditionally rhetorical analysis has been limited to fine grained linguistic analysis and detailed investigations into 'the art of persuasion' but Billig's (1991; 1996) work emphasises how rhetoric can be understood at a more fundamental level - as argumentation and as a way of thinking. The analysis here did not merely rehearse the different arguments put forward in this fiercely contested dispute, it showed that by arguing for something, stakeholders tended to argue against alternative views. Interviewees incorporated these into their positions by role-playing arguments with their opponents; by framing their arguments as responses to the criticisms of their adversaries; or wrestling with the internal consistency of their arguments. Analysing this argumentation helps us to understand the ways that influential stakeholders think about parks and therefore the ways these public spaces are socially constructed.

The research presented here demonstrates different attitudes towards public space and different ways of thinking about public parks - park imaginaries. These encompass varying attitudes regarding who and what public parks are for, different ideas about how parks should be funded, and diverse interpretations of the significance of temporary disruptions to park access. All stakeholders expressed their affection for Battersea Park, wanted it to remain public and were keen to avoid denigrating it. However, in expressing their support for, or resistance to, Formula E events they exhibited very different ideas about how parks should be 
maintained and developed. These differences were based on established divides: e.g. traditionalists versus modernisers; but were also underpinned by contrasts between those who value the everyday use value of parks and interests seeking to exploit their potential as visitor destinations. In Lowes' (2002) research, local groups resisting park based motor racing achieved success by presenting an alternative vision for their park. In this study, the 'success' of the Battersea Park Action Group and their allies was not achieved by promoting a specific vision or strategy for Battersea Park but through references to the contrast between the Formula $\mathrm{E}$ races and their park imaginary - one where users can enjoy unfettered access to a green, quiet and relaxing place. In an era where parks represent a complex and diverse range of environments, this illustrates the power of a traditional park imaginary in shaping attitudes and policy. Further research is needed to see if park imaginaries are evident in wider debates about park futures and to assess how imaginaries are created, circulated and strategically deployed.

This research did not specifically aim to assess the impacts of the Formula E events or suggest policy implications. However, in exploring the dispute, several important suggestions did emerge. Many stakeholders advocated the need for 'balance' between event use and everyday functions, and it would make sense to develop and enforce regulations that restrict the amount of time and space that ticketed events (and their preparations) can occupy. Events should be managed in a way that minimises disruptions to public access and there is a clear need for better communications between event organisers and park users. More research is now needed to take our understanding further. Empirical work is required to understand how events affect the ways urban parks are used and imagined. Battersea Park campaigners were concerned about the long term effects of temporary incursions; so longitudinal research is 
also needed to understand whether commercial events act as precedents for further privatisation and commercialisation. 


\section{References}

Arora P (2015) Usurping public leisure space for protest: Social activism in the digital and material commons. Space and Culture, 18(1): 55-68.

Besussi E (2016) Extracting value from the public city: urban strategies and the statemarket mix in the disposal of municipal assets. In S. Schipper and B. Schoenig (Eds.) Urban Austerity: impacts of the global financial crisis on cities in Europe (pp.89-102). Berlin: Theater der Zeit.

Billig M (1991) Ideology and Opinions: Studies in Rhetorical Psychology. London: Sage.

Billig M (1996) Arguing and Thinking: A Rhetorical Approach to Social Psychology. Cambridge: Cambridge University Press.

Braun V \& Clarke V (2006) Using thematic analysis in psychology. Qualitative Research in Psychology, 3(2): 77-101.

Burningham K, Barnett J \& Walker G (2015) An array of deficits: unpacking NIMBY discourses in wind energy developers' conceptualizations of their local opponents. Society \& Natural Resources, 28(3): 246-260.

Churchill D, Crawford A \& Barker A (2017) Thinking forward through the past: prospecting for urban order in (Victorian) public parks. Theoretical Criminology, 1362480617713986. 
Citroni S \& Karrholm M (2017) Neighbourhood events and the visibilisation of everyday life: The cases of Turro (Milan) and Norra Fäladen (Lund). European Urban and Regional Studies, 0969776417719489.

Crilley D (2003) Megastructures and urban change: aesthetics, ideology and design. In P Knox (Ed.) The Restless Urban Landscape (pp.127-164). Englewood Cliffs, NJ: Prentice Hall .

Davidson M (2013) The sustainable and entrepreneurial park? Contradictions and persistent antagonisms at Sydney's Olympic Park. Urban Geography, 34(5): 657-676.

Di Masso A, Dixon J \& Pol E (2011) On the contested nature of place: Figuera's Well', 'The Hole of Shame' and the ideological struggle over public space in Barcelona. Journal of Environmental Psychology, 31(3): 231-244.

Fairley S, Tyler B, Kellett P \& D’Elia K (2011) The Formula One Australian Grand Prix: Exploring the triple bottom line. Sport Management Review, 14(2): 141-152.

Flyvbjerg B (2006) Five misunderstandings about case-study research. Qualitative Inquiry, 12(2): 219-245.

Gaffikin F, Mceldowney M \& Sterrett K (2010) Creating shared public space in the contested city: The role of urban design. Journal of Urban Design, 15(4): 493-513. 
Gilmore A (2017) The park and the commons: vernacular spaces for everyday participation and cultural value. Cultural Trends, 26(1): 34-46.

Hansard (2016) House of Lords Debate on Contracting Out (Functions relating to the Royal Parks). Volume 776, $24^{\text {th }}$ Oct, 2016.

Harvey D (2009) Social Justice and the City. Revised Edition. Athens: University of Georgia Press.

Harvey D (2013) Rebel Cities: From the Right to the City to the Urban Revolution. New York: Verso.

Iveson K (2007) Publics in the City. Oxford: Wiley-Blackwell.

Jacobs K (2006) Discourse analysis and its utility for urban policy research. Urban Policy and Research, 24(1): 39-52.

Jakob D (2013) The eventification of place: Urban development and experience consumption in Berlin and New York City. European Urban and Regional Studies, 20(4), 447-459.

Jessop B \& Oosterlynck, S (2008) Cultural political economy: On making the cultural turn without falling into soft economic sociology. Geoforum, 39(3): 1155-1169. 
Keul A (2015) The fantasy of access: Neoliberal ordering of a public beach. Political Geography, 48: 49-59.

Lang S \& Rothenberg J (2017) Neoliberal urbanism, public space, and the greening of the growth machine: New York City's High Line park. Environment and Planning A, 49(8): 1743-1761.

Lasdun S (1992) The English Park: Royal, Private and Public. New York: Rizzoli International Publications.

Lees L (2004) Urban geography: discourse analysis and urban research. Progress in human geography, 28(10): 101-107.

Lehtovuori P (2016) Experience and Conflict: The Production of Urban Space. Hampshire: Ashgate.

Leitner H, Sheppard E, Sziarto K \& Maringanti A (2007) Contesting urban futures: decentering neoliberalism. In Leitner H, Peck J \& Sheppard E (Eds.) Contesting Neoliberalism: Urban Frontiers (pp. 1-25). Guildford: Guilford Press.

Loughran K (2014) Parks for profit: The High Line, growth machines, and the uneven development of urban public spaces. City \& Community, 13(1), 49-68.

Low S, Taplin D \& Scheld S (2009) Rethinking Urban Parks: Public Space and Cultural Diversity. Austin: University of Texas Press. 
Lowes M (2002) Indy Dreams and Urban Nightmares: Speed Merchants, Spectacle, and the Struggle over Public Space in the World-Class City. Toronto: University of Toronto Press.

Lowes M (2004) Neoliberal power politics and the controversial siting of the Australian Grand Prix motorsport event in an urban park. Loisir et Société/Society and Leisure, 27(1): 69-88.

Madden D (2010) Revisiting the end of public space: assembling the public in an urban park. City \& Community, 9(2): 187-207.

Mayer M (2013) First world urban activism: beyond austerity urbanism and creative city politics. City, 17(1): 5-19.

Meegan R, Kennett P, Jones G \& Croft J (2014) Global economic crisis, austerity and neoliberal urban governance in England. Cambridge Journal of Regions, Economy and Society, 7(1): 137-153.

Minton A (2017) Big Capital: Who is London for? London: Penguin.

Mitchell D (2003) The Right to the City: Social Justice and the Fight for Public Space. New York: Guilford Press. 
Mitchell D (2017) People's Park again: on the end and ends of public space. Environment and Planning A, 49(3): 503-518.

Németh J (2009) Defining a public: The management of privately owned public space. Urban Studies, 46(11): 2463-2490.

Oosterlynck S \& González S (2013) 'Don't waste a crisis’: Opening up the city yet again for neoliberal experimentation. International Journal of Urban and Regional Research, 37(3): 1075-1082.

Pine J and Gilmore J (1999) The Experience Economy. Cambridge, MA: Harvard Business Review Press.

Pløger J (2010) Presence-experiences. On the eventalisation of urban space. Environment and Planning D: Society and Space, 28: 848-866.

Potter J (1996) Representing Reality: Discourse, Rhetoric and Social Construction. London: Sage.

Richards G and Palmer R (2010) Eventful Cities. Oxford: Elsevier.

Salazar N (2012) Tourism imaginaries: a conceptual approach. Annals of Tourism Research, 39(2): 863-882. 
Sassen S (2017) The City: a collective good? Brown Journal of World Affairs, 23(2): 119126.

Schweinsberg S, Darcy S \& Cheng M (2017) The agenda setting power of news media in framing the future role of tourism in protected areas. Tourism Management, 62: 241-252.

Sendra P (2015) Rethinking urban public space: assemblage thinking and the uses of disorder. City, 19(6): 820-836.

Smith A (2014) 'Borrowing' public space to stage major events: The Greenwich Park controversy. Urban Studies, 51(2): 247-263.

Smith A (2016) Events in the City: Using Public Spaces as Event Venues. Abingdon: Routledge.

Smith A (2017) Animation or denigration? Using urban public spaces as event venues. Event Management, 21(5): 609-619.

Tranter P \& Lowes M (2009) Life in the fast lane. Environmental, economic and public health outcomes of motorsport spectacles in Australia. Journal of Sport and Social Issues, 33(2): $150-168$.

Van Deusen R (2002) Public space design as class warfare: Urban design, the right to the city and the production of Clinton Square, Syracuse, NY. GeoJournal, 58(2): 149-158. 
Vogler C (2002) Social imaginary, ethics, and methodological individualism. Public Culture, 14(3): 625-627.

Wandsworth Borough Council (2014) Planning Application Number 2014/6976.

Available at:

https://planning1.wandsworth.gov.uk/Northgate/PlanningExplorer/GeneralSearch.aspx Last accessed July $27^{\text {th }} 2017$.

Webster B (2015) Professor Nimby blows fuse over Formula E race. The Times, $25^{\text {th }}$ November, 2015. Available at: https://www.thetimes.co.uk/article/professor-nimbyblows-fuse-over-formula-e-race-30qxj0bn7jq Last accessed 19th July 2017.

Zukin S (2010) Naked City. The Death and Life of Authentic Urban Places. Oxford: Oxford University Press. 